\title{
Various Intragastric Balloons Under Clinical Investigation
}

\author{
Seong Ji Choi and Hyuk Soon Choi
}

Division of Gastroenterology and Hepatology, Department of Internal Medicine, Institute of Gastrointestinal Medical Instrument Research, Korea University College of Medicine, Seoul, Korea

Obesity is a chronic disease with an exponentially increasing incidence rate, and its negative effects are well documented in numerous studies. As a result, the importance of bariatric therapy cannot be overemphasized, and many bariatric treatment methods with varying mechanisms have been developed. Of the available treatment methods, intragastric balloons, introduced in the 1980s, have been shown to be a safe and effective treatment modality; various intragastric balloon products have been developed and are currently being widely used in clinical settings. However, the disadvantages of intragastric balloons, such as unclear long-term weight loss benefits and complications experienced during insertion and removal, preclude their wider use. In this review, we discuss different intragastric balloon products, focusing on those under clinical investigation, and suggest future research directions. Clin Endosc 2018;51:407-415

Key Words: Obesity; Endoscopy; Bariatrics; Intragastric balloons

\section{INTRODUCTION}

Obesity is a chronic disease characterized by excessive accumulation of adipose tissue in the body with resultant adverse health effects. It was not considered much as a disease several decades ago. However, the incidence rate of obesity has increased dramatically, and it has become a great global health concern. ${ }^{1}$ The problem with obesity is usually not with the disease itself but with the disease complications, such as diabetes, fatty liver disease, hypertension, heart disease, cerebrovascular disease, and metabolic syndrome. ${ }^{2}$ Its treatment is complex. The mainstay of obesity treatment is lifestyle modification, including diet control and exercise; other available options are weight loss pharmacotherapy, weight loss surgery,

Received: August 16, 2018 Revised: September 17, 2018

Accepted: September 17, 2018

Correspondence: Hyuk Soon Choi

Division of Gastroenterology and Hepatology, Department of Internal Medicine, Institute of Gastrointestinal Medical Instrument Research, Korea University College of Medicine, 73 Inchon-ro, Seongbuk-gu, Seoul 02841, Korea Tel: +82-2-920-6555, Fax: +82-2-953-1943, E-mail: mdkorea@gmail.com ORCID: https://orcid.org/0000-0002-4343-6950

(c) This is an Open Access article distributed under the terms of the Creative Commons Attribution Non-Commercial License (http://creativecommons.org/ licenses/by-nc/3.0) which permits unrestricted non-commercial use, distribution, and reproduction in any medium, provided the original work is properly cited. and endoscopic bariatric therapy (EBT). With the obesity market valued at 3.9 billion USD and a five-fold growth predicted over the next 6 years, the number of treatment options is expected to increase dramatically. ${ }^{3}$ Lifestyle modification with or without pharmacotherapy is the best initial treatment option; however, more definitive methods, such as bariatric surgery or EBT, are needed for individuals with morbid obesity. ${ }^{4}$ Bariatric surgery is the only long-term effective treatment for weight loss; however, it is indicated only for patients with severe obesity, including those with a body mass index (BMI) higher than $40 \mathrm{~kg} / \mathrm{m}^{2}$ or at least $35 \mathrm{~kg} / \mathrm{m}^{2}$ with comorbidities. Further, this surgery is limited by its complications and irreversibility. ${ }^{5}$ EBT plays a significant role in obesity treatment by filling the gap between pharmacotherapy and surgery, especially in patients with mild to moderate obesity who are unable to lose sufficient weight through lifestyle changes and pharmacotherapy or in those with morbid obesity who are aversive to surgery. ${ }^{6}$ EBT devices are designed for a similar weight loss function as well as improved safety, reversibility, and cost-effectiveness compared to bariatric surgery. ${ }^{7}$ The main mechanisms of EBT include space occupation, gastric capacity reduction, gastric motor function modification, and malabsorption. Of the many EBT devices developed, the space-occupying intragastric balloons (IGBs) are the most 
widely used in the clinical setting. ${ }^{8}$ This review discusses known IGBs, focusing on those under clinical trial investigations.

\section{INTRAGASTRIC BALLOONS}

Borrowing the idea from losing weight using gastric bezoars, IGB was first introduced in 1982, and the United States Food and Drug Administration (US FDA) approved the Garren-Edwards gastric bubble for obesity treatment in 1985. ${ }^{9,10}$ The satiety-inducing factors employed are gastric distension, gastric accommodation, and hormones, and the principal mechanism of weight loss using IGBs is delayed gastric emptying, which sustains gastric distension resulting in early satiation by vagal signals. ${ }^{11,12}$ The vagal nerve stimulation is triggered by gastric mechanoreceptors stimulated by gastric distension. ${ }^{13}$ The Garren-Edwards gastric bubble was withdrawn from the market owing to frequent complications associated with its use, such as gastric erosions and ulcers. Subsequently, balloons with the same working mechanism but with less complications were developed.

There are three commercially available IGBs approved for 6-month clinical use by the US FDA, i.e., ReShape Duo ${ }^{\mathrm{TM}}$ (ReShape Medical Inc., San Clemente, CA, USA), Orber$\mathrm{a}^{\mathrm{TM}}$ (Apollo Endosurgery, Austin, TX, USA), and Obalon ${ }^{\mathrm{TM}}$ (Obalon Therapeutics Inc., Carlsbad, CA, USA) (Tables 1 and 2). ${ }^{14-27}$ This review mainly focused on IGBs under clinical investigations, i.e., Spatz3 Balloon (Spatz FGIA, Great Neck, NY, USA), Elipse ${ }^{\mathrm{TM}}$ Balloon (Allurion Technologies, Wellesley, MA, USA), Heliosphere Bag (Helioscopie Medical Implants, Vienne, France), Medsil ${ }^{\mathbb{B}}$ (CSC MEDSIL, Moskovskaya oblast, Russia), LexBal (Lexel Medical, Buenos Aires, Argentina), End-ball (Endalis, Brignais, France), Adjustable Totally Implantable Intragastric Prosthesis (ATIIP)-Endogast ${ }^{\mathbb{}}$ (Districlass Medical, Chaponnay, France), Silimed Gastric Balloon (Silimed, Rio de Janeiro, Brazil), Semistationary Antral Balloon (SAB) (JP Industria Farmacéutica S.A., Ribeirão Preto, Brazil), Medicone ${ }^{\circledR}$ (Cachoeirinha, Brazil), and Ullorex ${ }^{\circledR}$ Oral Intragastric Balloon (Obalon Therapeutics Inc., San Diego, CA, USA/Phagia Technologies Inc., Stuart, FL, USA).

\section{SPATZ BALLOON}

The Spatz Adjustable Balloon (Fig. 1A) is a volume-adjustable saline-filled balloon approved for 1-year use. ${ }^{28}$ It is placed in the gastric cavity where it decreases the remnant volume and delays gastric emptying. The Spatz Balloon was introduced to overcome known limitations of earlier balloons, such as short-term implantation, difficulty in balloon volume adjustment, and balloon migration to the bowel. A unique feature of the Spatz Balloon is an extractable thin filling catheter that permits intragastric volume adjustment in situ. Since the volume of the balloon is externally adjustable, it can be adjusted according to patient tolerability and desired weight loss outcome. The Spatz Balloon, approved for 1-year implantation, has been granted the Conformité Européenne (CE) mark. It is widely used outside the US and is currently under multicenter clinical trial investigation in the US.

Machytka et al. implanted the Spatz Adjustable Balloon in 18 patients for 12 months, and the mean weight loss amounts at 24 and 52 weeks were $15.6 \mathrm{~kg}$ with $26.4 \%$ excess weight loss (EWL) and $24.4 \mathrm{~kg}$ with $48.8 \% \mathrm{EWL}$, respectively. ${ }^{28}$

Brooks et al. reported the results of 1-year implantation of the Spatz Adjustable Balloon in 73 patients. ${ }^{14}$ The patients had a mean weight loss amount of $21.6 \mathrm{~kg}$ (19\% of body weight) with $45.7 \%$ EWL. Catheter impaction was a major complication that occurred in three (4.1\%) patients and required surgical extraction; however, there were no mortalities recorded. ${ }^{14}$

Russo et al. compared the Spatz Adjustable Balloon with the BioEnterics Intragastric Balloon (BIB), also known as Orber$\mathrm{a}^{\mathrm{TM}}{ }^{29}$ In their case-control study, they compared the weight loss outcome, weight maintenance after removal, and shortand medium-term complications and found that there were no differences in these parameters observed between the two balloons. ${ }^{29}$ However, long-term safety issues of severe complications and high mortality have been reported. ${ }^{30}$ Further studies are needed to address the safety concerns.

\section{ELIPSE $^{\mathrm{TM}}$ BALLOON}

The Elipse ${ }^{\mathrm{TM}}$ Balloon (Fig. 1B) is the first procedureless IGB that is administered by swallowing, is self-emptying, and is naturally excreted. ${ }^{31}$ It is unique in that the balloon does not require anesthesia nor an invasive endoscopic procedure for insertion or removal. The balloon is enclosed in a vegetarian capsule and attached to a thin catheter. Once swallowed, its placement in the stomach is confirmed by fluoroscopy, and the balloon is externally filled up with saline through the catheter. After 4 months, the substance inside the balloon degrades, letting the balloon deflate, and the balloon is naturally excreted through the digestive tract. The ease of insertion and removal enables many physicians who do not perform endoscopy to be able to use the balloon; this is expected to lower the total cost of diet programs.

Machytka et al. implanted the Elipse ${ }^{\mathrm{TM}}$ device in 34 patients for 4 months, and after excluding one patient with aborted deployment and six patients with experimental balloon ma- 
Table 1. Intragastric Balloon Products Currently Available Worldwide

\begin{tabular}{|c|c|c|c|c|c|}
\hline Balloon products & Manufacturer & $\begin{array}{l}\text { Material } \\
\text { (Filled) }\end{array}$ & $\begin{array}{l}\text { Number of } \\
\text { balloons }\end{array}$ & $\begin{array}{l}\text { Duration } \\
\quad(\mathrm{mo})\end{array}$ & $\begin{array}{c}\text { Insertion/ } \\
\text { Removal method }\end{array}$ \\
\hline \multicolumn{6}{|c|}{ FDA Approved, CE Approved } \\
\hline Reshape Duo ${ }^{\mathrm{TM}}$ & ReShape Medical & $\begin{array}{l}\text { Silicone } \\
\text { (Saline } 450 \mathrm{~mL} \text { ) }\end{array}$ & 2 & 6 & $\begin{array}{l}\text { Endoscopic/ } \\
\text { Endoscopic }\end{array}$ \\
\hline Orbera $^{\mathrm{TM}}$ & Apollo Endosurgery & $\begin{array}{l}\text { Silicone } \\
\text { (Saline 400-700 mL) }\end{array}$ & 1 & 6 & $\begin{array}{l}\text { Endoscopic/ } \\
\text { Endoscopic }\end{array}$ \\
\hline Obalon $^{\mathrm{TM}}$ & Obalon Therapeutics & $\begin{array}{l}\text { Gelatin capsule } \\
\text { (Gas } 250 \mathrm{~mL})\end{array}$ & Up to 3 & $3-6$ & $\begin{array}{l}\text { Oral/ } \\
\text { Endoscopic }\end{array}$ \\
\hline \multicolumn{6}{|c|}{ Not FDA Approved, CE Approved } \\
\hline Spatz & Spatz FGIA Inc. & Silicone (Adjustable) & 1 & 12 & $\begin{array}{l}\text { Endoscopic/ } \\
\text { Endoscopic }\end{array}$ \\
\hline Elipse & $\begin{array}{l}\text { Allurion Technolo- } \\
\text { gies }\end{array}$ & $\begin{array}{l}\text { Polymer film (filled fluid } \\
450-550 \mathrm{~mL} \text { ) }\end{array}$ & 1 & 4 & $\begin{array}{l}\text { Oral/ } \\
\text { Natural excretion }\end{array}$ \\
\hline Heliosphere bag & Helioscopie & $\begin{array}{l}\text { Polyurethane and silicone } \\
\text { (Air } 550 \mathrm{~mL} \text { ) }\end{array}$ & 1 & 6 & $\begin{array}{l}\text { Endoscopic/ } \\
\text { Endoscopic }\end{array}$ \\
\hline MedSil & MedSil & $\begin{array}{l}\text { Silicone } \\
\text { (Saline 400-700 mL) }\end{array}$ & 1 & 6 & $\begin{array}{l}\text { Endoscopic/ } \\
\text { Endoscopic }\end{array}$ \\
\hline LexBal & Lexel Medical & $\begin{array}{l}\text { Silicone } \\
\text { (Saline 500-800 mL) }\end{array}$ & 1 & 6 & $\begin{array}{l}\text { Endoscopic/ } \\
\text { Endoscopic }\end{array}$ \\
\hline End-ball & Endalis & $\begin{array}{l}\text { Polyurethane } \\
\text { (Air/Saline } 600 \mathrm{~mL} \text { ) }\end{array}$ & 1 & 6 & $\begin{array}{l}\text { Endoscopic/ } \\
\text { Endoscopic }\end{array}$ \\
\hline \multicolumn{6}{|c|}{ Not FDA Approved, Not CE Approved } \\
\hline ATIIP(EndogAst ${ }^{\circledR}$ ) & Districlass Medical & $\begin{array}{l}\text { Polyurethane } \\
\left(\text { Air } 300 \mathrm{~cm}^{3}\right)\end{array}$ & 1 & $6-12$ & $\begin{array}{l}\text { Endoscopic-surgical/ } \\
\text { Not removed }\end{array}$ \\
\hline Silimed & $\begin{array}{l}\text { Slimed Industria } \\
\text { de Implantes }\end{array}$ & $\begin{array}{l}\text { Silicone } \\
\text { (Saline } 650 \mathrm{~mL}+\text { methy- } \\
\text { lene blue) }\end{array}$ & 1 & 6 & $\begin{array}{l}\text { Endoscopic/ } \\
\text { Endoscopic }\end{array}$ \\
\hline $\begin{array}{l}\text { Semistationary antral } \\
\text { balloon }\end{array}$ & $\begin{array}{l}\text { JP Industria } \\
\text { Farmaceutica }\end{array}$ & $\begin{array}{l}\text { Silicone } \\
\text { (Saline 150-180 mL + } \\
\text { methylene blue) }\end{array}$ & 1 & 6 & $\begin{array}{l}\text { Endoscopic/ } \\
\text { Endoscopic }\end{array}$ \\
\hline Medicone & Medicone & $\begin{array}{l}\text { Silicone } \\
\text { (Saline } 300-700 \mathrm{~mL}+ \\
\text { methylene blue) }\end{array}$ & 1 & 6 & $\begin{array}{l}\text { Endoscopic/ } \\
\text { Endoscopic }\end{array}$ \\
\hline $\begin{array}{l}\text { Ullorex oral gastric } \\
\text { balloon }\end{array}$ & $\begin{array}{l}\text { Obalon Therapeutics/ } \\
\text { Phagia Technologies }\end{array}$ & $\begin{array}{l}\text { Polymer } \\
\left(\mathrm{CO}_{2} 300 \mathrm{~cm}^{3}\right)\end{array}$ & $1-3$ & 1 & $\begin{array}{l}\text { Oral/ } \\
\text { Natural excretion }\end{array}$ \\
\hline
\end{tabular}

FDA, Food and Drug Administration; CE, Conformité Européenne; $\mathrm{CO}_{2}$, carbon dioxide.

ATIIP; Adjustable Totally Implantable Intragastric Prosthesis.

terial use, the remaining 27 patients showed 10\% weight loss; their other parameters, including BMI, glycated hemoglobin (HbAlc) level, and systolic and diastolic blood pressures, significantly improved, while no serious adverse events occurred. $^{15}$

Alsabah et al. conducted a multicenter prospective study on 135 patients for 4 months. ${ }^{32}$ The patients had a mean weight loss amount of $13.0 \mathrm{~kg}$ (15.1\% of body weight) and a mean BMI drop of $4.9 \mathrm{~kg} / \mathrm{m}^{2}$. Eight patients had their balloon removed early because of vomiting $(n=2)$, intolerance $(n=3)$, and early deflation $(n=3)$. The common adverse events were diarrhea in $18(13.3 \%)$ patients and colicky abdominal pain in 29
(21.5\%) patients, both occurring around the time of balloon deflation. One patient had small bowel obstruction because of balloon migration and underwent surgery. ${ }^{32}$

Two more cases of small bowel obstruction caused by Elipse $^{\mathrm{TM}}$ balloon migration and requiring surgical intervention were reported. ${ }^{33}$ More studies are required to address these concerns.

\section{HELIOSPHERE BAG}

The Heliosphere Bag (Fig. 1C) is an air-filled polymer bal- 


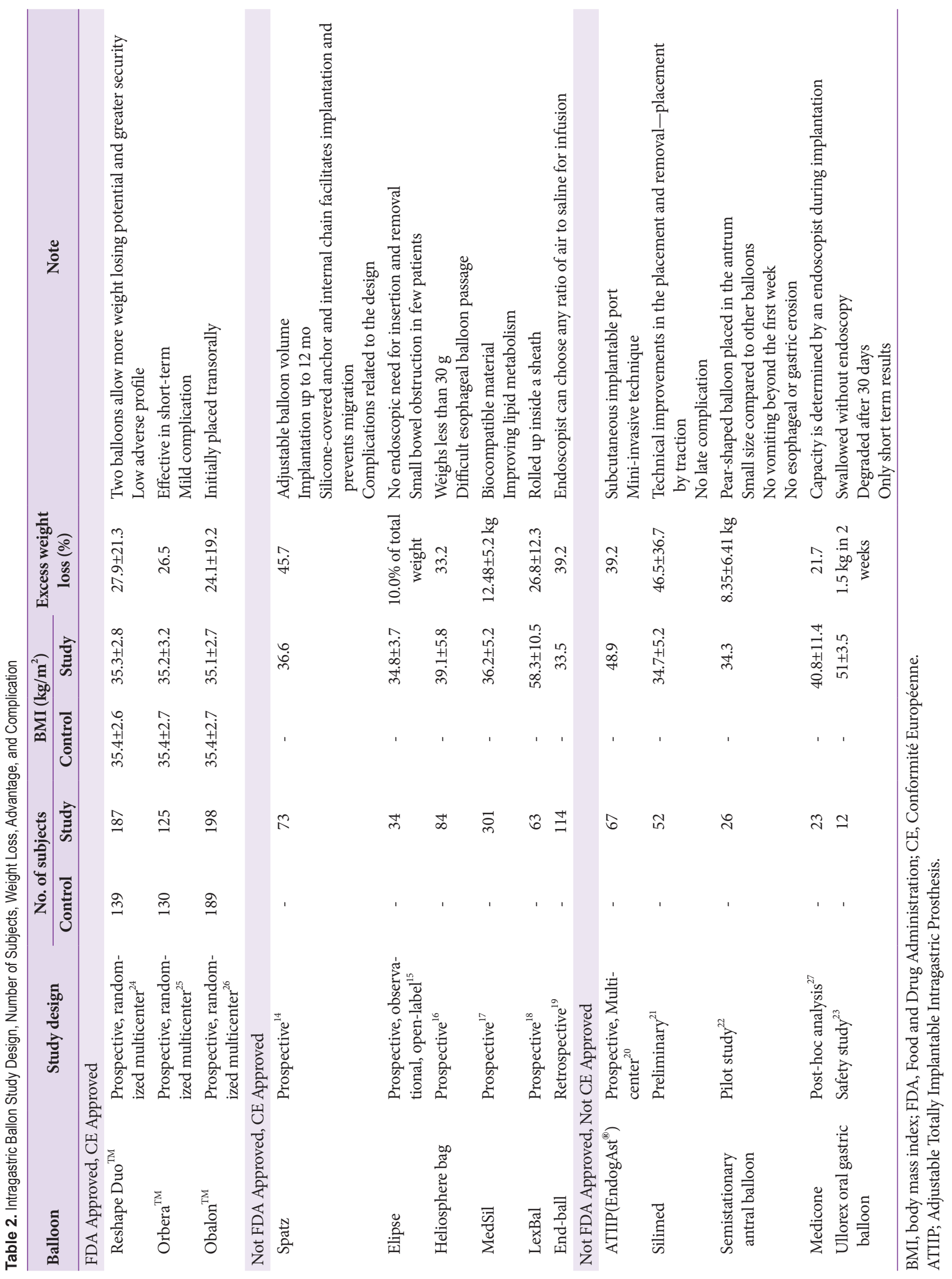


loon covered with a silicone envelope. ${ }^{34}$ Liquid-filled balloons were reported to induce nausea and vomiting around the time of balloon insertion in $10 \%-100 \%$ of patients due to excess balloon weight; thus, this air-filled device was introduced to circumvent this limitation. This endoscopy-inserted device weighs less than $30 \mathrm{~g}$, which is a 30 -fold mass reduction compared with that of the BIB, and it is approved for 6-month use.

Lecumberri et al. conducted a prospective study on the Heliosphere Bag in 82 consecutive patients with 6-month implantation. ${ }^{16}$ The mean weight loss amount was $14.5 \mathrm{~kg}$ with $33.2 \% \mathrm{EWL}$, and a mean BMI drop of $5.3 \mathrm{~kg} / \mathrm{m}^{2}$ with nausea and vomiting was reported in $7.4 \%$ of patients. ${ }^{16}$

Three studies have compared the air-filled Heliosphere Bag with the fluid-filled BIB; De Castro et al. and Giardiello et al. reported similar weight loss outcomes, while Caglar et al. reported the BIB as more effective for weight loss. ${ }^{35-37}$ Further, Giardiello et al. and De Castro et al. highlighted serious technical problems with the use of this balloon, i.e., difficult balloon passage through the cardia and the upper esophageal sphincter. ${ }^{36,37}$ Small bowel migration of the balloon was also

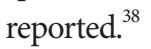

\section{MEDSIL $^{\circledR}$}

The Medsil ${ }^{\circledR}$ (Fig. 2A) is a saline-filled silicone balloon. ${ }^{39}$ This balloon is similar to Orbera ${ }^{\mathrm{TM}}$; however, according to the manufacturer, the Medsil ${ }^{\circledR}$ surpasses other balloons in terms of the biocompatibility of the silicone compound and is thereby better tolerated by patients and more economical.

According to Bužga et al., not only did the Medsil ${ }^{\mathbb{}}$ result in a mean weight loss amount of $18.4 \mathrm{~kg}$ and a mean BMI drop of $5.5 \mathrm{~kg} / \mathrm{m}^{2}$ in 6 months, but the balloon also had a positive effect on glucose tolerance, improving HbAlc levels significantly. ${ }^{39}$

Almeghaiseeb et al. reported a mean weight loss amount of $14.3 \mathrm{~kg}$ and a mean BMI drop of $5.2 \mathrm{~kg} / \mathrm{m}^{2}$ in 224 patients, and the complications that occurred during the study included pancreatitis in two patients, cardiac arrhythmia in one patient, and intestinal obstruction in two patients. ${ }^{17}$

\section{LEXBAL}

The LexBal (Fig. 2B) is a saline-filled silicone balloon, rolled up inside a sheath. Its structure and insertion and removal methods are similar to those of the Silimed Balloon.

In the study by Żurawiński et al. who implanted LexBal balloons in 63 patients with morbid obesity, the mean weight loss amount was $25.2 \mathrm{~kg}$, and the mean BMI reduction was 7.1 $\mathrm{kg} / \mathrm{m}^{2}{ }^{18}$ The common complications were nausea (57.1\%) and vomiting (44.4\%); however, no severe complications, such as mechanical intestinal obstruction or death, were reported. ${ }^{18}$
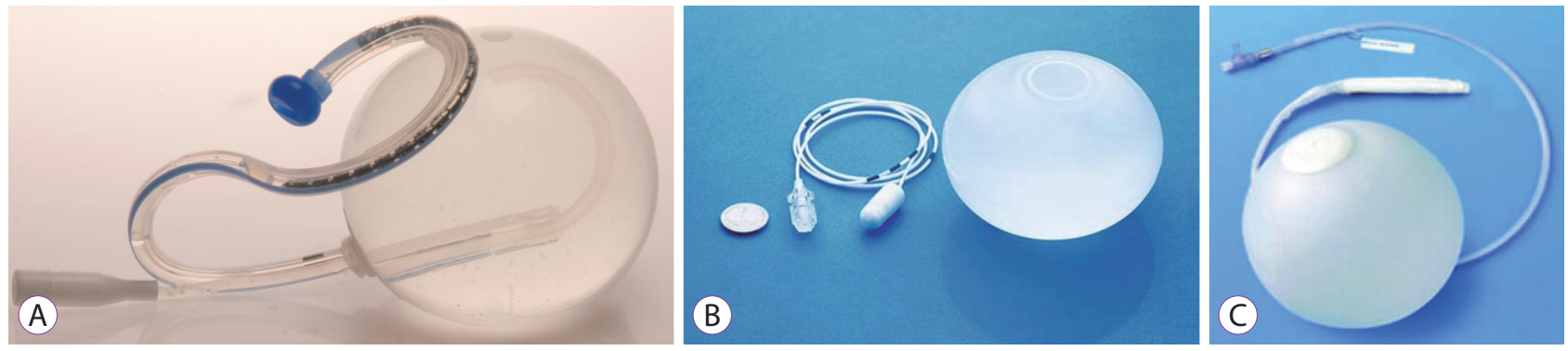

Fig 1. (A) Spatz3 Balloon. ${ }^{28}$ (B) Elipse ${ }^{\mathrm{TM}}$ Balloon. ${ }^{31}$ (C) Heliosphere Bag. ${ }^{34}$
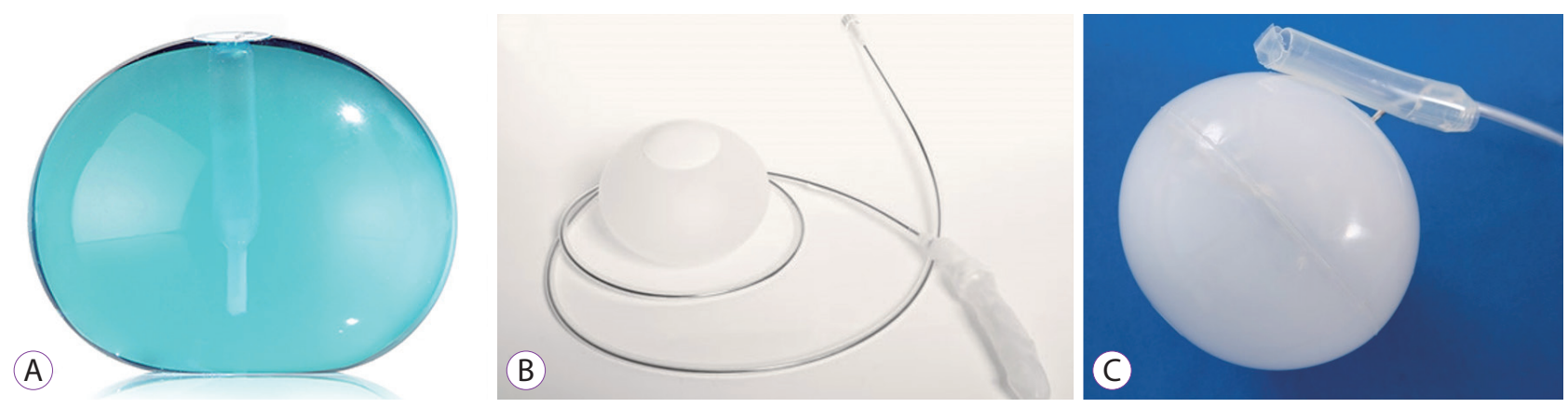

Fig 2. (A) Medsil ${ }^{\circledR 9}$ (B) LexBal (http://www.lexelmedical.com). (C) End-Ball (http://www.endalis.com). 


\section{END-BALL}

The End-ball (Fig. 2C), the most commonly used IGB in Korea, is a saline/air-filled spherical elastic polyurethane IGB. Conventional IGBs are filled with either saline or air, and both filling materials have advantages and disadvantages. The air-filled IGBs are well tolerated but less effective with regard to weight loss, while the saline-filled IGBs are superior in terms of weight loss results but with more complications. The unique feature of the End-ball is that the endoscopist can select any ratio of air to saline for infusion, and the balloon is inserted and removed using endoscopy.

Buzga et al. reported a mean weight loss amount of $14.7 \mathrm{~kg}$ with $32.1 \%$ EWL in 20 patients in 6 months. ${ }^{40}$ The results were similar to those of conventional balloons with a low incidence rate of complications. ${ }^{40}$ Keren and Rainis recently reported a mean weight loss amount of $23.5 \mathrm{~kg}$, a mean BMI reduction of $6.4 \mathrm{~kg} / \mathrm{m}^{2}$, and an EWL of $39.2 \%$ in 114 patients who were treated with the End-ball; the significant weight loss continued for 1 year after balloon removal. ${ }^{19}$

\section{ATIIP}

The ATIIP-Endogast ${ }^{\circledR}$ (Fig. 3A) is an air-inflated oval polyurethane IGB placed in the gastric corpus-fundus area. The balloon is placed in the proximal stomach to induce gastric accommodation reflex inhibition and neuro-hormonal disruption, which result in early satiety. The ATIIP-Endogast ${ }^{\circledR}$ is inserted via a combined endoscopic-surgical procedure, and the prosthesis in the stomach is connected to a subcutaneous totally implantable system to avoid dislocation and allow for volume adjustment. Gaggiotti et al. implanted the ATIIP in 57 patients and recorded mean BMI drops of $7.4 \mathrm{~kg} / \mathrm{m}^{2}$ at 3 months, $8.4 \mathrm{~kg} / \mathrm{m}^{2}$ at 6 months, and $12.2 \mathrm{~kg} / \mathrm{m}^{2}$ at 12 months; the mean EWL progressed from $22.3 \%$ at 3 months, $28.7 \%$ at 6 months, and $39.2 \%$ at 12 months. ${ }^{20}$ Nine patients had their balloons removed before 12 months; three patients underwent surgery after successful weight loss, and six patients showed no weight loss after routine follow-up. Five patients with successful weight loss had their balloon removed after more than 12 months. The common complications observed were local subcutaneous infection at the incision site (12.2\%), pneumoperitoneum (5.2\%), and air leak from the prosthesis (3.5\%). ${ }^{20}$ The balloon has been granted the CE mark; however, there are only a few studies on the ATIIP-Endogast ${ }^{\mathbb{Q}}$, and more studies are necessary.

\section{SILIMED BALLOON}

The Silimed Gastric Balloon (Fig. 3B) is a spherical transparent silicone balloon, rolled up inside a thin silicone sheath. ${ }^{21}$ The balloon inside the sheath is inserted to the stomach via endoscopy with direct visualization by holding it with a snare at the tip of the scope. After insertion, the balloon is filled with saline, contrast, and methylene blue and placed in the gastric fundus under endoscopic guidance. Contrast is used for better radiographic visualization of the device. Removal is also performed under direct endoscopic observation, and the balloon which has been emptied using a catheter is captured by a snare and removed via the overtube.

Carvalho et al. reported a mean weight loss amount of $11.3 \mathrm{~kg}$ with a mean BMI drop of $3.9 \mathrm{~kg} / \mathrm{m}^{2}$ in 14 patients following 6-month implantation of the Silimed Balloon. ${ }^{21} \mathrm{An}$ initial complication of epigastric pain was observed in $21 \%$ of the patients, and a late complication of spontaneous balloon deflation without migration to the intestine was seen in two patients near the end of the 6-month term. ${ }^{21}$

However, the CE certificates for all Silimed medical products, including the Silimed Gastric Balloon, were suspended in 2015 owing to a quality control issue with particle contamination; however, the Silimed Balloon is still used in other parts of the world.

\section{SEMISTATIONARY ANTRAL BALLOON}

The SAB (Fig. 3C) is a pear-shaped silicone balloon with a 30-cm-long duodenal stem and a 7-g metallic weight at its distal end. ${ }^{22}$ Compared with the aforementioned balloons, the SAB focuses on satiety caused by postprandial antral distension and sensory fullness. The mechanism of the SAB is antral and proximal duodenal satiety receptor stimulation by intermittent pyloric occlusion. Via endoscopy, the balloon is inserted and anchored in the antrum, with its proximal end within the antrum and the distal end positioned at the second duodenal portion with the duodenal stem. The balloon is then filled with $150-180 \mathrm{~mL}$ of saline containing contrast and methylene blue. After 6 months, the SAB is punctured and removed endoscopically.

Lopasso et al. inserted the SAB in 26 patients and reported a median weight loss amount of $6.5 \mathrm{~kg}$ over a mean period of 3.5 months. ${ }^{22}$ Weight loss was greater in patients who weighed over $90 \mathrm{~kg}$ and tolerated the SAB for 6 months. The SAB was well tolerated by patients because of its small size. The $S A B$ spontaneously ruptured in four patients (15\%), and of these, one patient had a small bowel obstruction and had the $S A B$ surgically removed. The $\mathrm{SAB}$ needs technical improvements 
and further investigations. ${ }^{22}$

\section{$\operatorname{MEDICONE}^{\circledR}$}

The Medicone $^{\circledR}$ (Fig. 3D) is a saline-filled silicone IGB. Its capacity, determined by an endoscopist during implantation, varies from 300 to $700 \mathrm{~mL}$. This balloon is widely used in South America; however, there are sparse clinical studies on this balloon. Pezzo et al. reported the study findings of 10 adolescent patients, which were similar to other study findings of adolescents. ${ }^{41}$ Neto et al. reported 5,172 cases of Medicone ${ }^{\circledR}$ use, comprising $12.4 \%$ of the total balloon implantations in Brazil, and the complications were also similar to those of other IGBs. $^{42}$

\section{ULLOREX $^{\circledR}$ ORAL INTRAGASTRIC BALLOON}

The Ullorex ${ }^{\circledR}$ Oral Intragastric Balloon is a large capsule that is ingested with injected citric acid. The unique feature of this balloon is that endoscopy is not needed for implantation or removal. The citric acid reacts with the sodium bicarbonate in the capsule and forms carbon dioxide, which gradually inflates the balloon to $300 \mathrm{~cm}^{3}$. After a month, a plug on the balloon is degraded by gastric acid, and the balloon is deflated spontaneously and removed by natural excretion through the digestive tract.

Martin et al. reported a mean weight loss amount of $1.5 \mathrm{~kg}$ over 2 weeks in 12 patients without serious complications. ${ }^{23}$ However, the size of the pill is too big to swallow easily, and there is a possibility of esophageal inflation. Further technical development with randomized controlled trials is needed.

\section{BALLOONS UNDER DEVELOPMENT}

The obesity market is a promising industry, and development of new products and supplementation of existing products are continuously on trial to overcome the limitations of conventional IGBs.

Do et al. developed a gas-filled spherical balloon with a magnetic soft capsule device. ${ }^{43}$ The magnetic capsule is controlled by an external magnetic field to open the inflation and deflation valves. The authors tested this balloon in porcine stomachs in vivo and successfully validated the inflation and deflation processes. Further studies on live animals and hu-
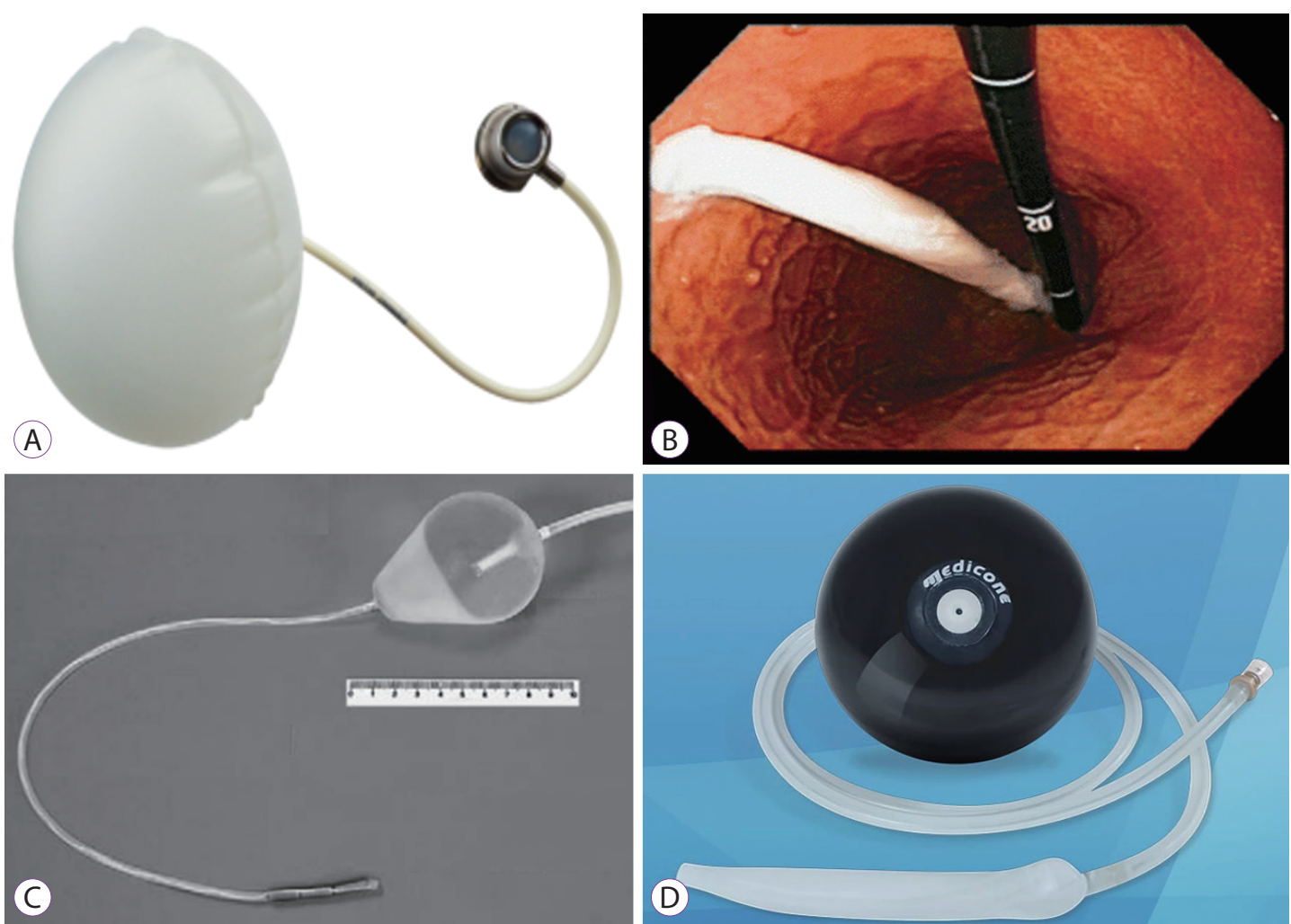

Fig 3. (A) Adjustable Totally Implantable Intragastric Prosthesis-Endogast ${ }^{\circledR}$ (http://districlass.com). (B) Silimed Gastric Balloon. ${ }^{21}$ (C) Semistationary Antral Balloon. ${ }^{22}$ (D) Medicone $^{\circledR}$ (https://www.medicone.com.br). 
mans are ongoing. ${ }^{43}$

There are other balloons that are currently under development; however, information on such is limited.

\section{COMBINATION THERAPY}

Obesity is a chronic disease, and its treatment should provide a long-term effect. The main limitation of IGBs is that their long-term weight loss outcome is still unclear. To overcome such, several methods are being studied. One trial is investigating the effects of combining IGBs not only with lifestyle modifications and pharmacotherapy but also with other types of endoscopic treatment devices that use different weight loss mechanisms.

Ghoz et al. conducted an animal study on combined IGB and duodenojejunal bypass sleeve, and the combination therapy significantly increased the levels of postprandial insulin. ${ }^{44}$ Further studies are necessary to verify whether this modality can be used in clinical settings.

\section{CONCLUSIONS}

Since the incidence rate of obesity does not seem to be decreasing but is rather expected to continue increasing rapidly, it is anticipated that the various bariatric devices will consequently keep evolving. In particular, EBT devices, including IGBs, play a role in bridging the gap between pharmacotherapy and surgery. In terms of reversibility, safety, and cost-effectiveness, EBT devices also have clear advantages over bariatric surgery, even though bariatric surgery has long-term weight loss benefits. ${ }^{45}$ Therefore, in deciding on the optimal treatment plan from the available treatment modalities, a holistic individualized approach that is frequently re-evaluated should be considered. Furthermore, physicians should remain flexible and be ready to switch treatment plans depending on patient dynamics.

In our review, the common complications of IGBs were nausea, vomiting, and discomfort, especially during their insertion and removal; however, the long-term weight loss benefits are yet to be proven. Further studies focusing on reducing the side effects of IGBs and enhancing the long-term weight loss benefits of IGBs and outcomes of repeated IGB insertion should be conducted.

\section{Conflicts of Interest}

The authors have no financial conflicts of interest.

\section{Acknowledgements}

This research was supported by a grant of the Korea Health Technology R\&D Project through the KHIDI, funded by the Ministry of Health \& Welfare, Republic of Korea (grant number: HI14C3477) and NRF of Korea grant funded by the Korea government (MSIP) (No. 2017R1C1B2006425).

\section{REFERENCES}

1. Ng M, Fleming T, Robinson M, et al. Global, regional, and national prevalence of overweight and obesity in children and adults during 1980-2013: a systematic analysis for the global burden of disease study 2013. Lancet 2014;384:766-781.

2. Segula D. Complications of obesity in adults: a short review of the literature. Malawi Med J 2014;26:20-24.

3. Grand View Research. Obesity treatment market size \& forecast, by drugs (combination drugs, appetite suppressants, malabsorption \& satiety drugs), by surgery \& devices (adjustable gastric banding, Rouxen-Y gastric bypass, sleeve gastrectomy, biliopancreatic diversion with duodenal switch, endoscopic procedures) and trend analysis to 2024 [Internet]. San Francisco (CA): Grand View Research; c2016 [updated 2016 Sep; cited 2018 Sep 20]. Available from: https://www.grandviewresearch.com/industry-analysis/obesity-treatment-devices-and-therapeutics-market.

4. Daniel S, Soleymani T, Garvey WT. A complications-based clinical staging of obesity to guide treatment modality and intensity. Curr Opin Endocrinol Diabetes Obes 2013;20:377-388.

5. Nguyen NT, Vu S, Kim E, Bodunova N, Phelan MJ. Trends in utilization of bariatric surgery, 2009-2012. Surg Endosc 2016;30:2723-2727.

6. Vargas EJ, Rizk M, Bazerbachi F, Abu Dayyeh BK. Medical devices for obesity treatment: endoscopic bariatric therapies. Med Clin North Am 2018;102:149-163.

7. Sullivan S, Edmundowicz SA, Thompson CC. Endoscopic bariatric and metabolic therapies: new and emerging technologies. Gastroenterology 2017;152:1791-1801.

8. Kim SH, Chun HJ, Choi HS, Kim ES, Keum B, Jeen YT. Current status of intragastric balloon for obesity treatment. World J Gastroenterol 2016;22:5495-5504.

9. Gleysteen JJ. A history of intragastric balloons. Surg Obes Relat Dis 2016;12:430-435.

10. Nieben OG, Harboe H. Intragastric balloon as an artificial bezoar for treatment of obesity. Lancet 1982;1:198-199.

11. Gomez V, Woodman G, Abu Dayyeh BK. Delayed gastric emptying as a proposed mechanism of action during intragastric balloon therapy: results of a prospective study. Obesity (Silver Spring) 2016;24:1849-1853.

12. Swidnicka-Siergiejko A, Wróblewski E, Andrzej D. Endoscopic treatment of obesity. Can J Gastroenterol 2011;25:627-633.

13. Kentish SJ, Page AJ. The role of gastrointestinal vagal afferent fibres in obesity. J Physiol 2015;593:775-786.

14. Brooks J, Srivastava ED, Mathus-Vliegen EM. One-year adjustable intragastric balloons: results in 73 consecutive patients in the U.K. Obes Surg 2014;24:813-819.

15. Machytka E, Gaur S, Chuttani R, et al. Elipse, the first procedureless gastric balloon for weight loss: a prospective, observational, open-label, multicenter study. Endoscopy 2017;49:154-160.

16. Lecumberri E, Krekshi W, Matía P, et al. Effectiveness and safety of airfilled balloon Heliosphere $\mathrm{BAG}^{\circledR}$ in 82 consecutive obese patients. Obes Surg 2011;21:1508-1512.

17. Almeghaiseeb ES, Ashraf MF, Alamro RA, Almasoud AO, Alrobayan AA. Efficacy of intragastric balloon on weight reduction: Saudi perspective. World J Clin Cases 2017;5:140-147.

18. Żurawiński W, Sokołowski D, Krupa-Kotara K, Czech E, Sosada K. Evaluation of the results of treatment of morbid obesity by the endo- 
scopic intragastric balloon implantation method. Wideochir Inne Tech Maloinwazyjne 2017;12:37-48.

19. Keren D, Rainis T. Intragastric balloons for overweight populations-1 year post removal. Obes Surg 2018;28:2368-2373.

20. Gaggiotti G, Tack J, Garrido AB Jr, Palau M, Cappelluti G, Di Matteo F. Adjustable totally implantable intragastric prosthesis (ATIIP)-Endogast for treatment of morbid obesity: one-year follow-up of a multicenter prospective clinical survey. Obes Surg 2007;17:949-956.

21. Carvalho GL, Barros CB, Okazaki M, et al. An improved intragastric balloon procedure using a new balloon: preliminary analysis of safety and efficiency. Obes Surg 2009;19:237-242.

22. Lopasso FP, Sakai P, Gazi BM, et al. A pilot study to evaluate the safety, tolerance, and efficacy of a novel stationary antral balloon (SAB) for obesity. J Clin Gastroenterol 2008;42:48-53.

23. Martin CK, Bellanger DE, Rau KK, Coulon S, Greenway FL. Safety of the Ullorex oral intragastric balloon for the treatment of obesity. J Diabetes Sci Technol 2007;1:574-581.

24. Ponce J, Woodman G, Swain J, et al. The REDUCE pivotal trial: a prospective, randomized controlled pivotal trial of a dual intragastric balloon for the treatment of obesity. Surg Obes Relat Dis 2015;11:874-881.

25. US Food and Drug Administration. Summary of safety and effectiveness data (SSED): ORBERA ${ }^{\text {st }}$ intragastric balloon system [Internet]. Silver Spring (MD): FDA; c2015 [updated 2015 Aug 5; cited 2018 Sep 20]. Available from: https://www.accessdata.fda.gov/cdrh_docs/pdf14/ P140008b.pdf.

26. US Food and Drug Administration. Summary of safety and effectiveness data (SSED): Obalon balloon system [Internet]. Silver Spring (MD): FDA; c2016 [updated 2016 Sep 8; cited 2018 Sep 20]. Available from: https://www.accessdata.fda.gov/cdrh_docs/pdf16/P160001b.pdf.

27. Borges AC, Almeida PC, Furlani SMT, Cury MS, Gaur S. Intragastric balloons in high-risk obese patients in a Brazilian center: initial experience. Rev Col Bras Cir 2018;45:e1448.

28. Machytka E, Klvana P, Kornbluth A, et al. Adjustable intragastric balloons: a 12-month pilot trial in endoscopic weight loss management. Obes Surg 2011;21:1499-1507.

29. Russo T, Aprea G, Formisano C, et al. BioEnterics intragastric balloon (BIB) versus spatz adjustable balloon system (ABS): our experience in the elderly. Int J Surg 2017;38:138-140.

30. Daniel F, Abou Fadel C, Houmani Z, Salti N. Spatz 3 adjustable intragastric balloon: long-term safety concerns. Obes Surg 2016;26:159-160.

31. Bazerbachi F, Vargas Valls EJ, Abu Dayyeh BK. Recent clinical results of endoscopic bariatric therapies as an obesity intervention. Clin Endosc 2017;50:42-50.
32. Alsabah S, Al Haddad E, Ekrouf S, Almulla A, Al-Subaie S, Al Kendari $M$. The safety and efficacy of the procedureless intragastric balloon. Surg Obes Relat Dis 2018;14:311-317.

33. Angrisani L, Santonicola A, Vitiello A, Belfiore MP, Belfiore G, Iovino P. Elipse balloon: the pitfalls of excessive simplicity. Obes Surg 2018;28:1419-1421.

34. Trande P, Mussetto A, Mirante VG, et al. Efficacy, tolerance and safety of new intragastric air-filled balloon (Heliosphere BAG) for obesity: the experience of 17 cases. Obes Surg 2010;20:1227-1230.

35. Caglar E, Dobrucali A, Bal K. Gastric balloon to treat obesity: filled with air or fluid? Dig Endosc 2013;25:502-507.

36. De Castro ML, Morales MJ, Del Campo V, et al. Efficacy, safety, and tolerance of two types of intragastric balloons placed in obese subjects: a double-blind comparative study. Obes Surg 2010;20:1642-1646.

37. Giardiello C, Borrelli A, Silvestri E, Antognozzi V, Iodice G, Lorenzo M. Air-filled vs water-filled intragastric balloon: a prospective randomized study. Obes Surg 2012;22:1916-1919.

38. Drozdowski R, Wyleżoł M, Frączek M, Hevelke P, Giaro M, Sobanski P. Small bowel necrosis as a consequence of spontaneous deflation and migration of an air-filled intragastric balloon - a potentially life-threatening complication. Wideochir Inne Tech Maloinwazyjne 2014;9:292296.

39. Bužga M, Evžen M, Pavel K, et al. Effects of the intragastric balloon MedSil on weight loss, fat tissue, lipid metabolism, and hormones involved in energy balance. Obes Surg 2014;24:909-915.

40. Buzga M, Kupka T, Siroky M, et al. Short-term outcomes of the new intragastric balloon End-Ball ${ }^{\circledR}$ for treatment of obesity. Wideochir Inne Tech Maloinwazyjne 2016;11:229-235.

41. Pezzo CT, de Souza TF, Fenero V, Suano-Souza FI, Grecco E, Sarni ROS. Efficacy and safety of intragastric balloon in the treatment of obesity in adolescent females. Nutrire 2017;42:26.

42. Neto MG, Silva LB, Grecco E, et al. Brazilian intragastric balloon consensus statement (BIBC): practical guidelines based on experience of over 40,000 cases. Surg Obes Relat Dis 2018;14:151-159.

43. Do TN, Ho KY, Phee SJ. A magnetic soft endoscopic capsule-inflated intragastric balloon for weight management. Sci Rep 2016;6:39486.

44. Ghoz HM, Acosta A, Topazian M, Camilleri M, Gostout C, Dayyeh BKA. A pre-clinical animal study of combined intragastric balloon and duodenal-jejunal bypass sleeve for obesity and metabolic disease. Gastroenterology 2016;150(4 Suppl 1):S231-S232.

45. Choi HS, Chun HJ. Recent trends in endoscopic bariatric therapies. Clin Endosc 2017;50:11-16. 